\title{
KOŃ TROJAŃSKI W MIEŚCIE NAUKI, CZYLI IMPRESJA O CUDOWNOŚCIACH I NIEREDUKOWALNOŚCIACH
}

\author{
Oto właśnie cały człowiek, \\ winę nogi zwala na but. \\ Vladimir \\ Samuel Beckett, Czekając na Godota \\ (tłum. Antoni Libera)
}

\section{Krótka introdukcja}

Trudno rozstrzygnąć, co było pierwsze - idea ewolucji czy idea projektu. Kiedy w 1859 r. Charles Darwin opublikował swoje rewolucyjne O powstawaniu gatunków, za sprawą Williama Paleya (por. Życiński 2014) atmosfera intelektualna przesycona już była manierą myślenia w kategoriach projektu. Starcie tych zupełnie różnych kultur refleksji eksplodowało sporem kreacjonistów z ewolucjonistami, który raz po raz odradza się aż po dziś dzień. Jednak ani Darwin ze swoimi pomysłami, ani Paley ze swoją argumentacją nie byli pierwszymi w swoich dziedzinach.

\section{Lekcja historii naturalnej}

Rzecz jasna Darwin jako pierwszy sformułował relatywnie spójną teorię wyjaśniającą mechanizm ewolucji jako właściwy samej przyrodzie i kierowany jej immanentnymi prawami. Jednak sam pomyst, by o przyrodzie myśleć nie w kategoriach raz na zawsze ustanowionego porządku rzeczy, ale porządku zmieniającego się w czasie, jest dużo starszy; ,[...] teoria Darwina o ewolucyjnym pochodzeniu gatunków nie pojawiła się na scenie myśli ludzkiej nagle i niespodziewanie. Był to w rzeczywistości jedynie logicznie następujący rozkwit myśli, która długo kiełkowała na gruncie europejskim" (Francoeur 1969, s. 66). Trzeba też wspomnieć Alfreda Russela 
Wallace'a - niezależnie od Darwina, równolegle opracował on teorię, której istotne składowe były tożsame $\mathrm{z}$ modelem zaproponowanym przez Darwina (Francoeur 1969). Jednym z bezpośrednich protoplastów Darwina był jego dziadek Erasmus Darwin. Nie bez znaczenia dla kształtowania przychylnego ewolucyjnemu myśleniu kontekstu naukowego jest sformułowana przez Charlesa Lyella teoria, zgodnie z którą litosfera i ukształtowanie powierzchni ziemi podlegały z biegiem czasu stopniowym przekształceniom. Wcześniej teorię ewolucji biologicznej opracował również Jean-Baptiste Lamarck i choć nie podał on przekonywującego wyjaśnienia przekształcania się gatunków, błędnie zakładając dziedziczenie cech nabytych, to niewątpliwym jest, że myślał już o różnorodności przyrodniczej jako o strukturze dynamicznej. Georges-Louis Leclerc de Buffon, przyjaciel Lamarcka, był o krok od sformułowania teorii ewolucji (por. Nowiński, Kuźnicki 1965); „[...] u Buffona znajdowało się niemal wszystko, co było konieczne do narodzin teorii doboru naturalnego" (Wendt 1961). Zdumiewające, że Karol Linneusz - twórca systematyki "usztywniającej” obraz przyrody - już po publikacji Systema Naurae "upłynniał” swą koncepcję na najniższych poziomach systematycznych; przyznawał coraz dobitniej, że granice między gatunkami i odmianami często są płynne, a nawet wysuwał coraz dalej idące hipotezy o pochodzeniu jednych odmian, podgatunków czy wręcz gatunków z krzyżowania się innych odmian, podgatunków i gatunków (por. Nowiński, Kuźnicki 1965).

Za ojca biologii słusznie uchodzi Arystoteles. Stagiryta bowiem jako pierwszy w dziejach zachodniej cywilizacji podjął tak szeroką, a zarazem metodologicznie usystematyzowaną refleksję nad przyrodą ożywioną. Uczeni skłonni są przypisywać Arystotelesowi zapośredniczonemu w filozofii Akwinaty winę za wizję świata niedającą się uzgodnić z dynamicznym obrazem przyrody ożywionej, jaki postuluje współczesna biologia (por. Francoeur 1969). Jednak sam Arystoteles zwracał uwagę na płynność przyrody. W Historia animalium możemy przeczytać, że - mówiąc językiem potocznym - granica między przyrodą nieożywioną a ożywioną jest tak rozmyta, że trudno ją wyznaczyć, a byty znajdujące się w środ$\mathrm{ku}$ spektrum różnorodności sprawiają problemy klasyfikacyjne; z kolei $\mathrm{z}$ De generatione animalium dowiadujemy się, że zdarza się w przyrodzie, że parzą się ze sobą nie tylko organizmy tego samego gatunku, ale też pewne stosunkowo niewiele się od siebie różniące (por. Nowiński, Kuźnicki 1965). Choć nie formułował Stagiryta koncepcji stricte ewolucyjnych, to świadom był problemów klasyfikacyjnego porządkowania bioróżnorodności, co stało się przecież w czasach późniejszych przyczyną formułowania modeli ewolucyjnych (por. Nowiński, Kuźnicki 1965). Już Anaksymenes wysunął hipotezę abiogenezy, że byty ożywione powstają z mułu. 
Empedokles zaś sformułował swoiście analogiczną do zjawiska doboru naturalnego koncepcję, wedle której natura w drodze spontanicznego procesu „wypróbowuje” niejako różne kombinacje składowych części organizmu, łącząc je rozmaicie, by wyszukać te najbardziej owocne (por. Francoeur 1969).

W okresie wczesnego chrześcijaństwa, w IV w. Efrem w swoim komentarzu do Księgi Rodzaju rozważał możliwość abiogenezy - spowodowanego spontanicznym działaniem natury powstania życia (por. Messenger 1931). Bazyli Wielki mówi o samorództwie węgorzy, myszy polnych, żab czy much. W innym miejscu rozważa „bardzo wyraźny przyczynowy związek pomiędzy ptakami a gadami”, stąd „wielu uczonych uważa Bazylego za jednego z wielkich chrześcijańskich prekursorów Darwina" (Francoeur 1969, s. 32). Grzegorz z Nyssy rozwinął natomiast wątek, który podjął Augustyn, formułując swoją teorię rationes seminales - racji zarodkowych. Bóg stworzył wszystkie byty w ich potencjalności, która we właściwym czasie rozwinęła się, dając początek kolejnym gatunkom. Mimo tych obiecujących antycypacji myśli ewolucyjnej rozwój filozofii, a później nauki i wraz z nimi teologii, zwrócił się w innym kierunku. Odkrycie pism Arystotelesa dla Zachodu i fascynacja nim spowodowała, że Akwinata, choć znał koncepcję rationes seminales Augustyna, zdecydował się jednak koniec końców interpretować stworzenie w arystotelejskiej, statycznej perspektywie. Być może również obawa przed herezją do której mogła prowadzić swoboda interpretacji Biblii postulowana przez szkołę aleksandryjska, przyczyniła się do nasycania atmosfery intelektualnej skłonnością do faworyzowania literalizmu biblijnego w duchu szkoły antiocheńskiej (por. Francoeur 1969); antiocheńska szkoła alegorezy wskutek rzeczonego literalizmu implicite wykluczała możliwość ewolucyjnego opisu przyrody ożywionej.

Tak więc stało się, na wieki rozwój kultury został zdominowany paradygmatem statycznym. Przez pewien czas nawet dało się w kontekście tegoż statycznego paradygmatu formułować relatywnie sensowne teorie, z których chyba najdoskonalszą jest wspomniany już system przyrody Linneusza. Wraz z rozwojem koncepcji statycznych coraz bardziej dojmujące stawało się pytanie o przyczyny takiego, a nie innego kształtu przyrody. Uczeni z jednej strony coraz dobitniej uświadamiali sobie niedoskonałości porządku przyrody, z drugiej nie umieli spojrzeć na harmonię świata inaczej niż jako na dzieło bezpośrednio boskie, nie umieli patrzeć na świat jako stwarzany, a nie stworzony. Skoro bowiem przyroda jest statyczna w swym uporządkowaniu, gatunki nie mogą przechodzić jedne w drugie, a świat musiał od początku swego istnienia wyglądać tak, jak wygląda dziś, a wszystkie gatunki i rodzaje wedle swego porządku muszą pochodzić bezpośrednio z boskiego aktu stwórczego. 


\section{Eksplikacja projektu}

Wraz ze statyczną wizją przyrody myśl Zachodu odziedziczyła po Arystotelesie i Akwinacie myślenie o przyrodzie ożywionej w kategoriach teleologicznych. Jeśli bowiem świat jest uporządkowany raz na zawsze, to jego ostateczna przyszłość nie jest nigdy niczym innym niż aktualizacją porządku odwiecznie obecnego w potencji. Trop ten sięga czasów przedarystotelejskich. Wątki teleologiczne odnajdujemy u wielu filozofów starożytnych, również u Platona, Heraklita i stoików (por. Meister 2018). W De natura deorum Cycerona odnaleźć możemy jeden z najdawniejszych przykładów teleologicznego dowodu na istnienie Boga (Cyceron 1960; Davies 1993). Najgłośniejszą historyczną postacią tego rodzaju argumentacji jest słynny argument Paleya. Inspiracji Paleya należy poszukiwać u Richarda Bentleya, współczesnego Newtonowi filologa, który zresztą korespondował z fizykiem, wymieniając refleksje filozoficzne i naukowe. O ile jednak Newton w Scholium do Principiów przedstawił obraz Boga objawiającego się w prawach przyrody, o tyle Bentley poszukiwał Boga tam, gdzie nauka nie dotarła (por. Życiński 2014). Paley podejmuje tego rodzaju inspirację i zauważa, że gdybyśmy spacerując wrzosowiskiem, natknęli się na leżący tam zegarek, nie przypuścilibyśmy nawet, że leżał tam od zawsze. Struktura zegarka jest bowiem uporządkowana z uwagi na cel. Owo ukierunkowanie na cel ewokuje myśl o zegarmistrzu, który zegarek zaprojektował i wykonał. Zarazem jednak struktury biologiczne również są uporządkowane teleologicznie - nogi służą do chodzenia, zwinne palce do skomplikowanych operacji manualnych, zadaniem serca jest pompować krew, a funkcją płuc jest czerpanie tlenu z powietrza. Skoro zatem systemy fizjologiczne są zwrócone w kierunku jakiegoś celu, nie mogą być dziełem ślepej przyrody, ale są - jak przekonuje Paley - zaprojektowane przez wyższą inteligencję, Boga ${ }^{1}$. Wydaje się, że tego rodzaju argumentacja jest szczególnie intuicyjnie chwytliwa - odpowiednio pobieżnie przyjęta, jest z pewnością przekonująca (Davies 1993). Chad Meister (2018, s. 162) rekonstruuje rozumowanie Paleya w pięciu krokach:

(1) Artefakty (takie jak zegarek), których konfiguracja przyporządkowuje środki celom, są rezultatami (ludzkiego) projektu.

(2) Dzieła natury, takie jak ludzka ręka, przypominają artefakty.

${ }^{1}$ Trzeba zaznaczyć, że myśl Paleya w istocie była jednak głębsza, podjął on bowiem do pewnego stopnia trop Newtonowski, koncepcję Boga działającego w prawach przyrody (por. Życiński 2014), jednak - jak to często bywa - do powszechnego, w pewnym sensie popularnego, nie naukowego sensu stricto obiegu intelektualnego inkorporowane zostały wątki teleologiczne jego myśli i w tym sensie stały się jego idee podłożem w istocie bardziej popularnego niż naukowego sporu między kreacjonizmem, ID i ewolucjonizmem. 
(3) Zatem dzieła natury są prawdopodobnie rezultatami projektu.

(4) Co więcej, dzieł natury jest więcej i są o wiele bardziej złożone.

(5) Zatem dzieła natury są prawdopodobnie wytworami wielkiego projektanta - o wiele potężniejszego i bardziej inteligentnego niż ludzki projektant.

Teleologiczny dowód na istnienie Boga stał się w XIX w. bardzo popularny. Być może popularności tej sprzyjały pewne zaszłości intelektualne - obok tomistycznej, przejętej od Arystotelesa teleologii również koncepcje takie jak mechanicyzm kartezjański, a także idealnie harmonizujący z mechanicyzmem, piorunujący dziewiętnastowieczny rozwój techniki, coraz powszechniejsze wykorzystanie silnika parowego i elektryczności. Ludzie w coraz większym stopniu otoczeni byli przez precyzyjne urządzenia produkowane przez innych ludzi w określonym celu. Wszystko to sprzyjało postrzeganiu ogółu rzeczywistości w kategoriach mechanistycznych czy, jak kto woli, dostrzeganiu w rzeczywistości jej mechanistycznych aspektów. W takiej sytuacji argumentacja posługująca się tak łatwo dostępną ogółowi analogią rokuje wyjątkowo dobrze, stąd też doczekała się wielu redakcji. Do pewnego stopnia analogiczne, teleologiczne argumentacje wysunęli też Frederick Robert Tennant i Pierre Lecomte du Noüy (por. Hick 1994). O sile przekonywania argumentu z projektu znakomicie świadczy to, że i dzisiaj znajduje on wielu zwolenników.

Współczesną formą tego argumentu jest teoria ${ }^{2}$ inteligentnego projektu, czyli po prostu ID, wokół którego zawiązał się cały ruch intelektualny zwany Ruchem Inteligentnego Projektu, szczególnie popularny w USA (por. Meister 2018). Jego pomysły importowane są do Polski przez niektórych badaczy, choćby Kazimierza Jodkowskiego, Dariusza Sagana czy Michała Chaberka (por. Jodkowski 2007; Sagan 2009; Chaberek 2014). Centralnym pojęciem ID jest „nieredukowalna złożoność”. Jest to taka struktura, w której usunięcie jakiejkolwiek składowej spowoduje, że nie będzie mogła ona pełnić przypisanej jej funkcji. Jeden z teoretyków ID, biochemik Michael Behe posłużył się w celu wyjaśnienia tej idei przykładem pułapki na myszy, która może funkcjonować wyłącznie wtedy, gdy wszystkie jej elementy są odpowiednio połączone. Zorientowane na cel struktury nieredukowalnie złożone nie mogą zdaniem teoretyków ID wyewoluować,

${ }^{2}$ Określenie koncepcji ID mianem „teorii” może budzić wiele zastrzeżeń, jej status naukowy może bowiem budzić wątpliwości (por. Heller 2013; Heller 2014; Sady 2015). Naukowość ID nie stanowi jednak przedmiotu niniejszego tekstu, stąd uwagi na ten temat pomijam. Na określenie ID mianem teorii zdecydowałem się natomiast ze względu na dość powszechną w literaturze praktykę, nie zaś ze względu na osobiste przekonania o zasadności takiej klasyfikacji rzeczonej koncepcji. By nie zadrażniać terminologicznych purystów ani nie prowokować już więcej refleksji wokół problematyki, która nie jest tematem wywodu, w dalszej części tekstu dołożę starań, by posługiwać się skrótem ID zamiast pojęciem "teoria inteligentnego projektu”. 
ewolucja bowiem zakłada stopniowe nawarstwianie się zmian i gromadzenie elementów składowych struktur biologicznych; struktura nieredukowalnie złożona może być natomiast funkcjonalna, a przez to faworyzowana w doborze naturalnym, jedynie gdy jest kompletna. Skoro struktury nieredukowalnie złożone nie mogły wyewoluować, konkludują badacze ID, musiały zostać zaprojektowane.

Detekcji nieredukowalnych złożoności służyć ma filtr eksplanacyjny. Jest to opracowana przez drugiego czołowego teoretyka ID Williama Dembskiego kilkustopniowa procedura metodologiczna, w toku której rozstrzyga się o możliwości bądź niemożliwości przypadkowego (ewolucyjnego) pojawienia się danego systemu biologicznego. Struktura nieredukowalnie złożona musi w pierwszej kolejności być przygodna, jeśli bowiem jest w kontekście przyrodniczym konieczna, wtedy siłą rzeczy nie odsyła do idei projektu. Jeśli jest przygodna, musi być też złożona, w przeciwnym razie jest zupełnie prawdopodobne, że pojawiła się przypadkiem. Jeśli natomiast jest złożona, to musi też być ukierunkowana na jakiś cel. Jeśli nie jest ukierunkowana, to jest przypadkowa, ukierunkowanie dowodzi natomiast projektu. Teleologiczna konstrukcja nie może być dziełem przypadku (por. Meister 2018). Przykładów nieredukowalnych złożoności doszukuje się ID w strukturach anatomicznych takich jak oko czy ucho, ale przede wszystkim wysuwa się tu przykłady z poziomu molekularnego - wić bakteryjną czy cykle biochemiczne.

\section{Stochastyczna ruletka}

Wątpliwe to szczęście, że Darwin opublikował swoją teorię w okresie, w którym myślenie teleologiczne było tak popularne ${ }^{3}$. Z pewnością powszechny teleologiczny klimat i bezrefleksyjna akceptacja tego stylu myślenia były jedną z przyczyn oburzenia, jakie wywołały idee brytyjskiego uczonego. Teoria ewolucji w kształcie z 1859 r., uderzyła w samo serce projektowej wizji świata. Cóż bowiem, jeśli nie przeczucie teleologicznie pojętego sensu stanowi istotę argumentacji z projektu? Jakiekolwiek dowodzenie o istnieniu projektu możliwe jest o tyle tylko, o ile presuponujemy, że przyroda jest uporządkowana celowo, a struktury biologiczne mają ściśle określone funkcje. Darwin zaproponował całkowicie odmienny, rewolucyjny paradygmat. Pokazał, że o przyrodzie ożywionej da się myśleć wyłącznie w kategoriach przyczynowych. Niemożliwe stało się możliwe. Autor O powstawaniu gatunków... nie tylko zasugerował, że to, co

${ }^{3}$ Sam Darwin, co ciekawe, pozytywnie odniósł się do argumentacji Paleya w jej zasadniczej postaci (Życiński 2014). Wydaje się jednak, że w toku kulturowej recepcji zaakcentowany został teleologiczny i projektowy aspekt myśli Paleya, który nie dawał dobrych podstaw dla uzgodnienia myśli teologicznej z naukową. 
wydawało się logicznie nie do pomyślenia, da się jednak pomyśleć, ale pokazał dokładnie, jak to pomyśleć. Pokazał, że biologia może obejść się bez kategorii celu. Dla opinii publicznej opanowanej skłonnością do intuitywnego myślenia teleologicznego (choćby i nieświadomą) było tego za wiele:

Przekonanie takie [o celowości przyrody - P.S.] znajduje [...] coraz mniej zwolenników w naukach przyrodniczych, gdyż do rozwoju tych nauk doprowadziły teorie, odwołujące się do konieczności fizycznej oraz do uwarunkowań przyczynowo-skutkowych. Ich popularność zaczęła się 200 lat przed Darwinem, wraz z powstaniem nowej fizyki (Życiński 2016, s. 118).

Adam Łomnicki widzi w wyjaśnianiu teleologicznym zjawisk przyrodniczych jedynie wygodny skrót myślowy (por. Łomnicki 2002). Choć pojawiają się również głosy przeciwne, jak choćby Francisco J. Ayali czy Franza M. Wuketitsa, wedle których nie da się usunąć z biologii wyjaśnień teleologicznych (por. Stopa 2001), można się jednak pokusić się o przypuszczenie, że zarzewiem nośnego sporu między kreacjonizmem a ewolucjonizmem jest $\mathrm{w}$ istocie rzeczy zderzenie dwóch paradygmatów filozoficznych, dwóch stylów myślenia - teleologicznego i kauzalnego, a może raczej roszczeń stylu teleologicznego, by uzupełniać niedopowiedzenia koncepcji kauzalnych. Styl teleologiczny bowiem niby ciecz przyjmująca kształt naczynia zapływa we wszelkie uchyłki rzeczywistości, do których myślenie kauzalne jeszcze nie dotarło.

\section{Złożoność nieprzypadkowa}

Pojęcie nieredukowalnej złożoności prowadzi nie tylko do pytania o projektanta, który skonstruował tę strukturę, ale też do pytania o naturę samego zjawiska zaprojektowania czy raczej naturę realizacji projektu. Pojęcie projektu przez osobę projektanta może kierować myśl ku Bogu, jednak teoretycy ID zastrzegają często, że niekoniecznie tylko Bóg mógł zaprojektować nieredukowalne złożoności - mogli to zrobić choćby kosmici (por. Sagan 2009). Jedno wydaje się wszakże w tym wszystkim pewne: realizacja projektu musiała przebiegać w jakiś nadnaturalny sposób. Zdarza się, że piewcy ID sugeruja że sposobem realizacji projektu mogła być ewolucja. O ile jednak $\mathrm{z}$ punktu widzenia koncepcji inteligentnego projektu takie rozstrzygnięcie jest zbawienne, pozwala bowiem uzgodnić (pozornie) ID z biologią ewolucyjna, a wskutek tego pomaga uniknąć konfrontacji z biologami ewolucyjnymi, o tyle z punktu widzenia biologii ewolucyjnej tego rodzaju spekulacje są pozbawione podstaw. Ewolucja jest procesem napędzanym przez losową zmienność genetyczną i dobór naturalny, przy czym oba te zjawiska są „ślepe" i nie mają w swym 
działaniu żadnego w ogóle celu, a więc również nie mogą niczego projektować pod kątem funkcji. Tak rozumiane projektowanie wymaga bowiem, jak każde teleologicznie określone działanie, antycypacji przyszłości, wglądu w przyszłość, którego losowa zmienność i dobór naturalny nie są w stanie uzyskać. Nieredukowalna złożoność ex definitione nie może być skutkiem działania przypadku, a więc nie może być dziełem ewolucji rozumianej tak, jak rozumie się ją we współczesnej biologii. Nie pozostaje w tym miejscu nic innego niż przywołać na pomoc rzeczone nadnaturalne siły, które miałyby w ślepy porządek przyrody wkroczyć i w najlepszym razie wykorzystać mechanizmy biologiczne do wygenerowania nieredukowalnych złożoności. Można jeszcze rozważyć ewentualność, w przypadku której to inne inteligentne formy życia, zorganizowane racjonalnie w wymiarze biologicznym, w toku jakiejś dziwnej panspermii wyhodowały życie ziemskie. Niemniej na ten moment nie dysponujemy przekonującymi danymi empirycznymi, które pozwoliłyby zakładać istnienie takich istot. Zarazem jednak nawet gdybyśmy przyjęli ich istnienie, trudno zakładać, że organizacja ich życia w wymiarze populacyjno-biologicznym jest oparta na jakichś innych regułach niż te, które rozpoznała na Ziemi biologia środowiskowa. Ponadto nawet założenie istnienia takich istot tak naprawdę jedynie odsuwa, a nie usuwa pytanie o genezę układów niere-

80 dukowalnie złożonych. Można byłoby jeszcze założyć, że te obce formy życia nie miałyby w swoich strukturach biologicznych układów nieredukowalnie złożonych. Taka ewentualność wydaje się jednak trudna do wyobrażenia, ponadto jest czystą spekulacją bez oparcia w dostępnych danych empirycznych.

Ostatecznie więc groźba konieczności odwołania się do nadnaturalnych przyczyn nie zostanie zażegnana. Jeśli ma być racjonalnym przypuszczenie, które czasem formułują teoretycy ID, że ziemskie życie biologiczne jest nieredukowalnie złożone, ale - by nie odwoływać się do Boga - mogło zostać stworzone przez inne inteligentne istoty z Kosmosu, których struktury już są redukowalne, to racjonalne jest również przypuszczenie, które w obronie neodarwinizmu formułują biolodzy i filozofowie, że z tego, że nie rozumiemy, jak dana złożoność mogła wyewoluować, nie wynika, że wyewoluować nie mogła, a jedynie że my tego nie rozumiemy. Różnica polega tylko na tym, że tłumaczenie protagonistów ID odsuwa hipotezę redukowalności na jakieś odległe planety i cywilizacje, a biolodzy odsuwają problem redukowalności w odległe rewiry paleobiologicznej historii życia na Ziemi. W tej sytuacji okazuje się koniec końców, że piewcy ID albo przyjmą nadnaturalną przyczynę abiogenezy i ukształtowania biologicznych złożoności, albo - chcąc utrzymać narrację wolną od uwikłań metafizycznych i teologicznych - stwierdza, że ostatecznie życie jest redukowalnie złożone, z tym tylko zastrzeżeniem, 
że redukowalność ta jest zapośredniczona przez obce cywilizacje, których konstrukcji nie znamy. Rozwiązanie to jednak w istocie rzeczy niczym (prócz ewentualnej lokalizacji redukcji we Wszechświecie na tej czy innej planecie) nie różni się od rozwiązania proponowanego w biologii. $W$ jednym przypadku nie wiemy, jak mogłaby wyglądać redukcja biologiczna złożoności, a w drugim owo „nie wiemy” eksportujemy na jakąś bliżej nieokreśloną odległą planetę i w filogenetyczną przeszłość jakiejś obcej cywilizacji. W ten sposób, jeśli pojęcie nieredukowalnej złożoności nie ma być znaczeniowo puste, musi zakładać nadnaturalną ingerencję $\mathrm{w}$ bieg rzeczy. Ingerujące $\mathrm{w}$ naturalny bieg rzeczy nadnaturalne siły natomiast wprost przywodzą na myśl kategorię cudu. ID zatem implikuje, że geneza życia, przynajmniej w odniesieniu do jego nieredukowalnych aspektów, ma nadnaturalny, cudowny charakter.

\section{Cud nieprawdopodobieństwa}

Święty Tomasz stwierdził, że cuda (w jednym z kilku przyjmowanych przez Akwinatę rozumieniu) to takie działania Boga, w których czyni On coś, czego natura sama nie byłaby w stanie uczynić (por. Davies 1993). Wydaje się, że z tak rozumianym cudem mamy do czynienia w przypadku projektowania i ukształtowania nieredukowalnej złożoności. Jest to najpopularniejsza definicja cudu. David Hume przykładowo twierdzi podobnie, że cud to złamanie praw przyrody przez bóstwo lub jakiś niewidzialny czynnik (por. Hume 1977). Richard Swinburne i John Leslie Mackie również charakteryzują cuda analogicznie, jako zawieszenie praw przyrody (por. Davies 1993). Podobny trop wspomina Życiński (2014). Takie rozumienie cudu ma swoich krytyków. Samuel M. Thompson zauważa, że nie jest ono zgodne $\mathrm{z}$ biblijnym rozumieniem cudu, Reginald H. Fuller natomiast, że pojęcie prawa przyrody (względem którego definiuje się tradycyjnie cud) obce jest tradycji biblijnej (por. Davies 1993), ergo nie jest możliwe, żeby przekaz biblijny zakładał takie pojęcie cudu. Możliwe są oczywiście inne teorie cudu. Adam Świeżyński (2018) mówi również o znakowej i aksjologicznej koncepcji cudu, w podobnym duchu Życiński (2014) wspomina o psychologicznym i egzystencjalnym znaczeniu cudu. Te koncepcje jednak zakładaja, że istotą cudu jest komunikacja, a pomijają mechanizmy zachodzenia cudu w rządzonej prawami przyrodzie. W tym sensie nie wydają się kompletne, nie korelują też $\mathrm{z}$ argumentem teleologicznym i z tego względu nie będą nas tu zajmować.

Za Świeżyńskim (2018) przyjmijmy trzy możliwe ontologie cudu: (1) interwencjonistyczna, (2) instrumentalistyczną i (3) działań prostych. Wedle koncepcji (1) cud jest nadzwyczajną ingerencją Boga w bieg 
wydarzeń poprzez zawieszenie działania praw przyrody. Zgodnie z ujęciem (2) Bóg, działając cuda, wykorzystuje potencjalne właściwości przyrody, które są w naturalnym biegu zdarzeń niezmiernie mało prawdopodobne - wykorzystuje nietypowe koincydencje i przypadki tudzież anomalie. Koncepcja (3) przedstawia przyrodę w całości zależną od woli Boga, który czyni cuda bez jakiegokolwiek pośrednictwa.

Koncepcja nieredukowalnej złożoności w zasadzie nie da się pogodzić z instrumentalistyczną koncepcją cudu. W przeciwnym wypadku należałoby przyznać, że w pozostawionej samej sobie naturze tkwią pewne potencjalne możliwości, by ów nieredukowalnie złożony układ mógł się wyłonić, co samo w sobie winno już budzić zastrzeżenia w kontekście ID. Gdyby Bóg istotnie wykorzystał te utajone w materii możliwości, by wyprodukować cykl biochemiczny, należy przypuścić, że z perspektywy obserwatora ów cykl byłby jednak biologicznie redukowalny, dałby się wyjaśnić przez odniesienie do tychże utkwionych w materii możliwości. W ten sposób patrząc, nawet jeśli Bóg zbudował złożoności biologiczne, to robił to (budował) zgodnie z prawami natury, a nie wbrew nim, a zatem należałoby przyjąć, że złożoności biologiczne są wytłumaczalne w kontekście praw przyrody, bez względu na to, czy stoi za nimi Bóg, czy sama natura. Taki wniosek usprzecznia jednak ID. Wcielając się w protagonistów ID, moglibyśmy rzecz jasna oponować w tym miejscu, że realizacja tych potencji była skrajnie nieprawdopodobna, więc skoro się zaktualizowała, ktoś musiał pomóc szczęściu. Ale taka replika błędnie zakłada, że zdarzenia mało prawdopodobne nie mogą się zdarzyć; innymi słowy, że jeśli prawdopodobieństwo jakiegoś zdarzenia zmierza do 0 , to wynosi 0 , co jest trywialnym absurdem. Możemy jednak wysnuć przypuszczenie innego rodzaju, że mianowicie tym większe jest prawdopodobieństwo, że ktoś pomógł szczęściu, im mniejsze było prawdopodobieństwo zajścia zdarzenia, które się dokonało. Jednak jest to konkluzja niedokładna. Dziwić bowiem może jedynie występowanie jakiegoś zjawiska w dostatecznie długim czasie z częstością większa, niżby to sugerowało prawdopodobieństwo jego wystąpienia. Gdy natomiast częstość występowania koreluje z prawdopodobieństwem, nie ma w tym nic dziwnego i nie wydaje się zasadne wzywanie na pomoc niewidzialnej ręki. Dziwić może, gdy w 100 kolejnych rzutach monetą 99 razy wypadła reszka. Nie ma jednak nic dziwnego w tym, że reszka wypadła 47 razy. Dziwić mogłoby, że życie, którego spontaniczne powstanie jest tak dalece nieprawdopodobne, powstawałoby w każdej kałuży. Nie może jednak racjonalnie dziwić, że powstało spontanicznie - jak się to przyjmuje w teoriach abiogenezy - raz, około 4 miliardów lat temu na przestrzeni przeszło 13 miliardów lat historii Wszechświata. 
Wobec tego cud stworzenia nieredukowalnej złożoności ma albo naturę interwencjonistyczna, albo działania prostego. Zgodnie z koncepcją cudu jako działania prostego,

\begin{abstract}
przyroda jest [...] rozumiana jako sfera procesów i zdarzeń, wśród których mogą pojawić się nowe, całkiem nieoczekiwane i niewystępujące uprzednio zdarzenia, gdyż całkowicie podlega ona woli Boga i reaguje na wyrażone przez niego pragnienia. Nie oznacza to pogwałcenia jej praw, lecz raczej wzbogacenie możliwości jej funkcjonowania w sytuacji każdorazowego wyrażenia względem niej woli ze strony Boga (Świeżyński 2018, s. 271).
\end{abstract}

Takie ujęcie problemu w zasadzie usuwa w ogóle pojęcie praw przyrody. W tym duchu okazują się one złudzeniem, którego doznajemy, patrząc na regularność przyrody. Porządek świata nie wynika z żadnych reguł zadanych światu, ale $z$ utrwalonej tendencji w woli Boga. Gdy zgodzimy się na takie postawienie sprawy, koncepcja nieredukowalnej złożoności traci sens, bo jakakolwiek redukowalność jest po prostu złudzeniem. Jedyna możliwa w tym ujęciu redukowalność to redukowalność wszystkiego do woli Boga. Nieredukowalna złożoność, która miała być czymś szczególnym w przyrodzie, pewnym wyjątkiem od reguły, który dało się wykryć z pomocą filtra eksplanacyjnego, okazuje się tu rzeczą nader pospolitą. Koncepcja nieredukowalnej złożoności jest formą zastrzeżenia względem ewolucjonizmu. Zgodnie jednak z koncepcją cudów jako działań prostych cała teoria ewolucji traci rację bytu. Po cóż byłoby obaloną teorię poddawać refutacji? Zarazem jednak z perspektywy koncepcji cudu jako działania prostego samo pojęcie nieredukowalnej złożoności jest definiowane zbyt wąsko, a sito filtru eksplanacyjnego - zbyt drobne.

Ostatnią możliwością jest interwencjonistyczna koncepcja cudu i ta akurat wydaje się uzgadnialna z koncepcją nieredukowalnej złożoności. Koncepcja interwencjonistyczna zakłada, że Bóg, czyniąc cuda, omija prawa przyrody, zawiesza ich działanie. Otóż prawem przyrody jest, jak twierdzą zwolennicy ID, że powstanie nieredukowalnej złożoności w toku Darwinowsko rozumianej ewolucji jest niemożliwe. Wobec tego konieczne jest zawieszenie tego prawa, zawieszenie losowości tudzież doboru naturalnego i wprowadzenie do przyrody struktur, które biologicznie rzecz biorąc nie powinny były się pojawić, tak jak patrząc z perspektywy chemii, Postaci Eucharystyczne nie powinny przemienić się w krew czy strzępek mięśnia sercowego, tak jak patrząc z pespektywy fizyki, ikona nie powinna płakać, a medycznie rzecz biorąc, terminalnie chory nie powinien wyzdrowieć. 


\section{Zarzewie błędu}

Pojęcie cudu jako zjawiska nadnaturalnego ${ }^{4}$ wiąże się z pytaniem o kryteria demarkacji cudu, o podstawy pozwalające uznać jakieś wydarzenie za cudowne. Święty Tomasz w Summa contra gentiles dokonuje pewnej kategoryzacji cudów ze względu na stopień bezpośredniości boskiej interwencji (por. Davies 1993). Są więc cuda, (1) w przypadku których Bóg czyni coś, czego natura nigdy nie mogłaby uczynić, są to cuda, można by rzec, par excellence; ale są też (2) cuda, które natura mogłaby uczynić, gdyby porządek rzeczy był inny; i w końcu są (3) cuda, które natura mogłaby uczynić, ale czyni je Bóg. Trzecie rozumienie cudu wydaje się najsłabsze - są to, jak się zdaje, zjawiska, które co do istoty rzeczy dzieją się w przyrodzie na mocy reguł jej gry, ale w pewnych konkretnych wypadkach dzieją się za sprawą boskiej interwencji. Drugie rozumienie cudu jest nieco mocniejsze. Natura mogłaby takie zjawisko zdziałać, gdyby jej koleje potoczyły się nieco inaczej, ale że potoczyły się $\mathrm{w}$ ten, a nie inny sposób, interweniuje Bóg i pomimo przygodnych nieprzychylności działa cud. Pierwsze rozumienie cudu jest najmocniejsze. Tak pojętego zjawiska natura z definicji nie może spowodować, może je wywołać jedynie Bóg. Jest więc to cud uczyniony nie wbrew przygodnej sytuacji naturalnej, ale wbrew koniecznemu porządkowi naturalnemu.

Z punktu widzenia obserwatora cud rozumiany na trzeci sposób jest w zasadzie raczej nie do rozpoznania, gdyż zjawisko, które w tym przypadku jest cudowne, równie dobrze może być skutkiem boskiej interwencji, jak działania przyczyn naturalnych. Rozstrzygnięcie o cudowności jest $\mathrm{w}$ tym przypadku niezmiernie trudne, o ile nie niemożliwe. Jak bowiem rozstrzygnąć, czy w konkretnym wypadku życiodajny deszcz spadł na pola uprawne, bo zrządził tak Bóg, czy dlatego, że po prostu tak potoczyły się procesy pogodowe na mocy zadanych im praw? W przypadku obu ewentualności skutek jest ten sam - na pola uprawne spadł konieczny dla pożądanej obfitości plonów deszcz. Podobnie rzecz ma się w przypadku z zasady uleczalnej choroby. Jedynym, co może budzić wątpliwości, jest niezwyczajnie szybki proces zdrowienia. Jednak nie z takim cudem mamy do czynienia w przypadku powstania nieredukowalnej złożoności. Jeśli bowiem, jak postulują teoretycy ID, ma być nieomal trywialne, że pewne struktury nie mogły wyewoluować, to cudowność pojawienia się tej struktury $\mathrm{w}$ organizmach żywych staje się dość ewidentna. Nie można

${ }^{4}$ Inaczej rozumianych cudów nie biorę tutaj pod uwagę. Naturalnie jednak funkcjonuje wiele pojęć cudu, o czym napomknąłem wcześniej, zainteresowanych natomiast odsyłam do cytowanej już literatury, a także do prac poświęconych ściśle temu zagadnieniu, jak choćby (Bouflet 2011; English 2008; Corner 2007; Rusecki 2006; Ashe 1978; Swinburne 1970). 
też zgodzić się, że koncepcji inteligentnego projektu wystarczy pojęcie cudu w drugim jego rozumieniu, czyli jako zdarzenia, które zasadniczo jest możliwe w porządku naturalnym, ale ze względu na jakieś przygodne zaszłości, jak choćby zepsucie grzechu, nie może w tej chwili wystąpić. Koncepcja ID nie zakłada bowiem, że złożoność mogłaby wyewoluować, ale $\mathrm{z}$ jakichś przygodnych przyczyn $\mathrm{w}$ znanej nam historii naturalnej nie wyewoluowała - przeciwnie, uczeni skupieni wokół pojęcia ID twierdzą coś mocniejszego, mianowicie że z przyczyn fundamentalnych, na mocy boskim nakazem zadanych praw przyrody złożoność nie mogła wyewoluować. Pojęcie ID wymaga wobec tego mocnego pojęcia cudu jako zdarzenia, które nie jest możliwe przyrodniczo rzecz biorąc i może zajść wyłącznie za sprawą boskiej interwencji.

Mocne pojęcie cudu, powtórzmy, definiuje cud jako zdarzenie zachodzące $\mathrm{w}$ przyrodniczym świecie, które jest niemożliwe $\mathrm{z}$ uwagi na rządzące przyrodą prawa, wobec czego może zajść wyłącznie za sprawą boskiej interwencji. Jeśli jednak weźmiemy pod uwagę niekończącą się historię nauki i jej zasadniczo indeterministyczny rozwój, owa niemożliwość przyrodnicza staje się bardzo kłopotliwa, w sensie filozoficznym, składową koncepcji cudu. Z uwagi na nieustanny postęp nauki nie jest możliwe sformułowanie rozstrzygającego, nierelatywnego historycznie argumentu dowodzącego naukowej niewyjaśnialności jakiegoś zjawiska (por. Życiński 2014). Nie jest odkrywczym stwierdzenie, że rozwój nauk przyrodniczych właśnie na tym polega, że wyjaśniają one z czasem zjawiska i problemy wcześniej niezrozumiałe. O ile nie można racjonalnie przypuścić, że kiedykolwiek nauka wyjaśni wszystko (zresztą czym owo "wszystko" miałoby być?), o tyle nie można też racjonalnie twierdzić w przypadku dowolnego jednego zjawiska, że nauka nigdy go nie wyjaśni. A właśnie zasadnicza niewyjaśnialność zjawiska jest w myśl filozofii Akwinaty świadectwem jego cudowności. Zresztą tego rodzaju warunek cudowności funkcjonuje w obrębie doktrynalnych rozstrzygnięć Kościoła również dziś. Bo choć przypisuje się cudom również funkcję dydaktyczna, to jednak podstawą oficjalnego uznania cudu jest orzeczenie przyrodników o niewyjaśnialności zjawiska metodami naukowymi. Rzecz w tym, że owa niewyjaśnialność zawsze jest przygodna, jest historycznie relatywną sytuacja która w dowolnej chwili może ulec zmianie wskutek jakiegoś rewolucyjnego odkrycia naukowego. Możemy rozważyć nawet tak abstrakcyjny przypadek osoby (rzecz, która wedle mej wiedzy nie zaszła mimo wielu innych, rozmaitych poświadczonych cudów), która w wyniku nieszczęśliwego wypadku straciła nogę. Wedle współczesnej wiedzy kończyna nie może tej osobie odrosnąć. Jeśliby więc odrosła i można by racjonalnie przypuszczać, że odrosła w związku z pobożnymi praktykami poszkodowanego, należałoby to uznać za cud. Nie można jednak 
wykluczyć, że będzie to pierwszy przypadek ekspresji wcześniej utajonej w genotypie, do tej pory nierozpoznanej zdolności, która w toku ewolucji na przestrzeni przyszłych kilku milionów lat stanie się własnością zupełnie pospolitą u naszych potomków.

Analogonem mocnego pojęcia cudu wydaje się w pewnym sensie, biorąc pod uwagę dotychczasowe refleksje, koncepcja Boga luk (por. Bylica 2004), która swymi korzeniami sięga postaci Samuela Clarke’a, zwolennika wypełniania luk poznawczych hipotezą Boga (por. Życiński 2014). Różnią się obie idee jedynie powszechnością zjawisk, do których się odnoszą. Gdy mamy do czynienia z jednostkowym, rzadkim zdarzeniem, którego nie umiemy wyjaśnić, będziemy mówili o cudzie zdziałanym przez Boga. Gdy natomiast będziemy mieli do czynienia ze zjawiskiem powszechnym, które nie zostało wyjaśnione przez naukę, wtedy bezpośrednio odwołamy się do Boga jako koniecznej przyczyny tam, gdzie nie umiemy znaleźć przyczyn naturalnych. Nie wspomnimy o cudzie, nie ma bowiem praw, które Bóg miałby tu zawiesić, ale luce pośród praw, w której odsłania się boska istność. Wyłania się z tych rozważań wizja rzeczywistości, której zjawiska dają się podzielić na trzy kategorie ze względu na to, co jest ich bezpośrednią przyczyną. Pierwszą składową rzeczywistości są zjawiska spowodowane przyczynami naturalnymi. Drugą składową są zjawiska powszechne niewyjaśniane w kategoriach naturalnych. Trzecią składową są zjawiska niewyjaśniane i sporadyczne, czyli cuda. Styl refleksji, który jest przedmiotem naszych tu rozważań, każe w przypadku drugiej i trzeciej składowej doszukiwać się sprawstwa Bożego. Jeśli bowiem nie przyroda zdziałała to, co niewyjaśniane i cudowne, to musiał to zdziałać Bóg. Jest to jednak wizja nader nieelegancka. By miało bowiem sens, luki muszą być właściwe porządkowi ontologicznemu, nie epistemologicznemu, a w takim wypadku boskie dzieło okazuje się niedopracowane. Zwłaszcza $\mathrm{w}$ perspektywie teleologicznej ciśnie się wtedy na usta nieco ironiczne pytanie: czy wszechmocny Bóg nie mógł był stworzyć świata całkiem samowystarczalnego? Z perspektywy teisty we wszystkich trzech przypadkach mamy do czynienia z boskim przyczynowaniem, osobliwym wydaje się więc, że przypadki drugi i trzeci miałyby być jakoś szczególnie uprzywilejowane w poszukiwaniu Boga. Można wysnuć przypuszczenie, że za koncepcjami cudu i nieredukowalnej złożoności stoi pewien dualizm, zgodnie z którym dane zjawisko albo ma swą przyczynę w prawach naturalnych, albo w Bogu. Z jednej strony, logicznie rzecz biorąc, dualizm ten nie wyklucza roli Boga jako prawodawcy w przypadku zjawisk wyjaśnianych naturalistycznie, niemniej z drugiej, nieco psychologizując, można przypuścić, że doszukiwanie się $\mathrm{w}$ niektórych zjawiskach fundamentalnej niewyjaśnialności i związanej z nią konieczności wskazania na Boga jako przyczynę tych zjawisk jest symptomem słabej wiary, która niby Niewierny Tomasz poszukuje namacalnych znaków obecności Boga w świecie. 
Choć istotnie Bóg luk w logicznym sensie nie wyklucza Boga Pantokratora, który ma pod swą władzą również przyczyny naturalne, historia chwytliwego, acz nieostrożnego pomysłu Bentleya, jego intelektualnego spadkobiercy Paleya i wynikłego z ich koncepcji zamętu intelektualnego wokół teorii ewolucji poucza, że należy wystrzegać się tego rodzaju pochopnych uproszczeń nie tylko z uwagi na błędy samych tych koncepcji. Koncepcja Boga luk, nieredukowalnej złożoności czy mocna koncepcja cudu zawdzięczają swą chwytliwość chyba dość nieszczęśliwej intuicji, wedle której Bóg bardziej jest Bogiem, gdy działa bezpośrednio, niż gdy działa za pośrednictwem praw przyrody. Intuicja ta zdaje się widzieć w prawach przyrody równorzędnych Bogu pomocników w dziele stworzenia, których współudział ujmuje chwały boskiej potędze. Bóg jest więc bardziej obecny w cudach, które czyni bezpośrednio, niż w porządku przyrody, który współtworzy z natura. Gdyby rzeczywiście prawa przyrody miały w stwarzaniu swój współudział, Bóg rzeczywiście bardziej byłby autorem cudów niż świata. Prawa przyrody są jednak takim samym stworzeniem jak ptactwo niebieskie, tak samo Bogu podległym i w nich tak samo jak w każdym innym stworzeniu Bóg jest obecny.

\section{Repryza subiektywna}

Cudowność i nieredukowalność - obie, podobnie jak koncepcja luk poznawczych, zakładają naukową niewyjaśnialność, przeto jak sama niewyjaśnialność, są kategoriami relatywnymi i historycznie zmiennymi. W toku wieków różne zjawiska będą pod te kategorie podpadały, a różne będą z ich zakresu wypadały. Przypuszczalnie nauka wyjaśni kolejne cuda, obracając ich cudowność w naturalność (por. Życiński 2014), odkryje za to kolejne, których nikt się nie spodziewał. Niepodobna więc dowodzić, że wrażenie cudowności kiedykolwiek zniknie nam z horyzontu, ku któremu zmierzamy. Niepodobna jednak również przypuszczać, że cuda istnieją w jakimkolwiek mocnym sensie. Albo wszystko jest cudem, albo nic. Jakie racje prócz subiektywnych, często niezmiernie ważnych dla życia duchowego wzruszeń mogą przemówić za twierdzeniem, że czymś bardziej zdumiewającym jest, gdy Hostia staje się strzępkiem mięśnia sercowego, niż gdy mocą przez Boga ustanowionych praw w toku ewolucji powstaje Wszechświat, a potem Człowiek? Czemu Bóg miałby być większym cudotwórca, gdy leczy paralityka, niż wtedy, gdy rękami lekarza przywraca choremu zdrowie albo gdy ustanawia prawa fizyczne? Chyba właśnie zestawienie Boga cudownie uzdrawiającego i lekarza uzdrawiającego naturalnie choć, jak wierzą teiści, z dopustu Bożego, najdobitniej pozwala odczuć, jak bardzo subiektywną i relatywną kategorią jest kategoria cudu. 
Z nieredukowalnością jest inaczej. O ile cudowność jest bowiem sprawą religii i mitu, który napędza świat i w istocie przejawia się $\mathrm{w}$ całości Stworzenia, a nie tylko w jego części, o tyle nieredukowalność rości sobie prawo do bycia sprawą nauki. Nieredukowalność domaga się, by nauka z możliwości wnioskowała o konieczności. Pod przykrywką nieredukowalności usiłuje się $\mathrm{w}$ istocie wprowadzić do nauki zupełnie obce nauce pojęcie cudu wbrew naturze samego tego pojęcia, pod które podpada albo wszystko, albo nic. W ten sposób koń trojański przypuszcza szturm na rubieże nauki.

\section{Bibliografia}

Ashe G. (1978), Miracles, Routledge - Kegan Paul, London.

Beckett S. (1985), Czekajac na Godota, PIW, Warszawa.

Bouflet J. (2011), Historia cudów, Oficyna Naukowa, Warszawa.

Bylica P. (2004), Bóg luk a granice nauki, referat wygłoszony na III Filozoficznym Forum Młodych, http://www.nauka-a-religia.uz.zgora.pl/images/Inne.teksty/Bylica_Bog.luk. a.granice.nauki.pdf (dostęp: 2.01.2020).

Chaberek M. (2014), Stworzenie czy ewolucja?, Fronda, Warszawa.

Corner D. (2007), The Philosophy of Miracles, Bloomsbury Publishing, London.

Cyceron (1960), Pisma filozoficzne, PWN, Warszawa.

Davies B. (1993), Wprowadzenie do filozofii religii, Prószyński i S-ka, Warszawa.

English A. (2008), Ślady Boga. Cuda Kościoła Katolickiego, Świat Książki, Warszawa.

Francoeur R.T. (1969), Horyzonty ewolucji, PAX, Warszawa.

Heller M. (2013), Filozofia przypadku, Copernicus Center Press, Kraków.

Heller M. (2014), Przedmowa do trzeciego i czwartego wydania polskiego, [w:] E. McMullin, Ewolucja i stworzenie, przeł. J. Rodzeń, Copernicus Center Press, Kraków, s. 5-11.

Hick J. (1994), Argumenty za istnieniem Boga, Znak, Kraków.

Hume D. (1977), Badania dotyczace rozumu ludzkiego, PWN, Warszawa.

Jodkowski K. (2007), Spór ewolucjonizmu z kreacjonizmem, podstawowe pojęcia i poglady, Megas, Warszawa.

Łomnicki A. (2002), Ekologiczne i behawioralne konsekwencje ewolucji [w:] H. Krzanowska, A. Łomnicki, J. Rafiński i in. (red.), Zarys mechanizmów ewolucji, Wydawnictwo Naukowe PWN, Warszawa, s. 215-263.

Meister C. (2018), Wprowadzenie do filozofii religii, przeł. D. Misztal, T. Sieczkowski, Wydawnictwo Uniwersytetu Łódzkiego, Łódź.

Messenger E.C. (1931), Evolution and Theology, Burnes and Oates, London.

Nowiński C., Kuźnicki L. (1965), O rozwoju pojęcia gatunku, PWN, Warszawa.

Rusecki M. (2006), Traktat o cudzie, Wydawnictwo KUL, Lublin.

Sady W. (2015), Czego Kazimierz Jodkowski nie dostrzega, jeśli o odkrycia naukowe chodzi?, [w:] P. Bylica, K.J. Kilian, R. Piotrowski i in. (red.), Filozofia - Nauka-Religia. Ksiegga Jubileuszowa dedykowana Profesorowi Kazimierzowi Jodkowskiemu z okazji 40-lecia pracy naukowej, Oficyna Wydawnicza Uniwersytetu Zielonogórskiego, Zielona Góra, s. 59-64.

Sagan D. (2009), Spór o nieredukowalną złożoność, Megas, Warszawa.

Stopa A. (2001), Filozoficzne aspekty koncepcji teleologicznych w biologii (studium historyczno-krytyczne), [w:] K. Kloskowski, M. Lubański (red.), Z zagadnień filozofii przyrodoznawstwa i filozofii przyrody, Wydawnictwo UKSW, Warszawa, s. 75-145. 
Swinburne R. (1970), The Concept of Miracle, Macmillan - St. Martin's Press, London.

Świeżyński A. (2018), Jak uratować cud?, [w:] J. Hołówka, B. Dziobkowski (red.), Filozofia religii. Kontrowersje, Wydawnictwo Naukowe PWN, Warszawa, s. 267-288.

Wendt H. (1961), Szukałem Adama, t. 1-2, Wiedza Powszechna, Warszawa.

Życiński J. (2014), Transcendencja i naturalizm, Copernicus Center Press, Kraków.

Życiński J. (2016), Cel i konieczność ezwolucji [w:] M. Heller, J. Życiński, Dylematy ewolucji, Copernicus Center Press, Kraków, s. 117-127.

Streszczenie: Koń trojański w mieście nauki, czyli impresja o cudownościach i nieredukowalnościach

Celem tekstu jest ukazanie wzajemnego uwikłania pojęcia cudu i pojęcia nieredukowalnej złożoności. W tekście przeprowadzona została analiza porównawcza obu pojęć w kontekście historycznym i współczesnym. Teoria inteligentnego projektu implikuje kategorię cudu. Pojęcie cudu jest problematyczne $\mathrm{z}$ punktu widzenia filozofii religii i filozofii nauki. $\mathrm{W}$ ten sposób teoria ID z jednej strony przemyca do nauki kategorię zupełnie nauce obca, eksplanacyjnie nieefektywną kategorię cudu. Z drugiej natomiast przyjmuje koncepcję Boga luk, która jest kłopotliwa $\mathrm{z}$ teologicznego punktu widzenia, ponieważ ujmuje Bogu wszechmocy.

Słowa kluczowe: cud, filozofia nauki, filozofia religii, nieredukowalna złożoność, teoria ewolucji, teoria inteligentnego projektu, Bóg luk, wszechmoc, panenteizm, teleologia, argument teleologiczny

Summary: The Trojan Horse in the City of Science, or Impression on Miracles and Irreducible Complexity

The aim of this text is to show the mutual entanglement of the concept of miracle and the concept of irreducible complexity. The text contains a comparative analysis of both concepts in a historical and contemporary context. Intelligent design theory implies a idea of miracle. The concept of miracle is problematic from the point of view of philosophy of religion and philosophy of science. In this way ID theory on one hand bring into science a completely unfamiliar category, a category of miracle which is totally ineffective in explanation. On the other hand it assumes the God of the gaps concept, which is troublesome from the theological point of view, because it offend God's omnipotence.

Keywords: miracle, philosophy of science, philosophy of religion, irreducible complexity, theory of evolution, intelligent design theory, God of the gaps, omnipotence, panentheism, teleology, teleological argument 